酸アトロピンと組み合せて使用された。

筫入法としては,ラボナールによる rapid induction が半数使われ，次いで GOF, GOP によるSlow induction が使われ，エーテルの開放点滴法も使用されて いた。插管法は経口法, 経鼻法とも，ほぼ同数用いられ ていることがわかり，比較的，経鼻法の多いことが理解 出来ました。麻酔維持法は GOP，GOF，GOE・NLA をそれぞれ組み合せて，バランス林酔が中心であること がわった．また合併症として麻酔中に喘息発作が 1 例, チューブ脱管によるチアノーゼが 3 例みられ，麻酔後に 喉頭痙卛 1 例があり，乙れらは適切に処置され，事無き を得ているが，1例のみ麻酔覚醒し，帰室した後，その 夜，心不全にて死亡した症例があった。

\title{
14. 筑盛時における常温重合レジンの粘性変化
}

\section{○守川 雅雄・三宅 茂澍・岩谷 秀明 豊田 静夫 (九菓大・補経 1 ) 松下 伸一・井上勝一郎}

(九料大・理工)

一連の鋳造操作において，バターン材料になる wax の果す役割は，極めて重要であるが， wax が熱可塑性: で非常に低い融点をもっているために破折ならびに変形 し易いとと, 細部の精細なハターンを得るには, 十分浴 融し，流動性を简めなくてはならないため口腔内での直 接取扱いが困難であるととなどから，翡近では wax に 代わる材料として，いくつかのパターン用常温重合レジ ンが市販されている。だがてれらの材料がwaxに較べて どの様な性質を有するかについては，まだ十分研究がな されていない.このパターン材料としてのレジンには, 臨休上極めて有用な点が多いため是非ともその性質を究 明しておく必要がある. 铬って, 現在市販されているレ シンから手掛けて, 将来, 再現精度, 経時的変化, 流動 性,表面滑沢性, 焼却性等, それらを当目的のために使用 する際の広義の操作法について明らかにしてゆきたいと 考え, 今回は, その手始めとしで, Unifast, Duralay, Palavit の3 種類のパターン用レジンに, 対象材料とし $\tau$ Repairsin を加元, 粘度の測定, 走査型電顕を用い ての䒠際の粒子の観祭，E型粘度計による粘度変化，レ シン内部の温度変化等を検傠した。 その結果, 粒度分布

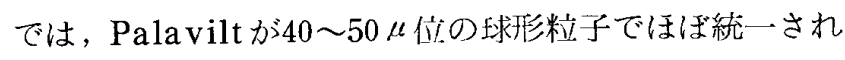
ているのに效して Unifast, Duralay では, 小さな粒 度への集申はあったが 0 〜200 示し, かつ削片状粒子が多数観察された. 一方, 粘性上
昇速度では, Unifast, Duralay, Palavit の順に急激 な立ち上がりを示したが，乙れには削片状のものが大き く関与しているのではないかと考えられた。また，外部 の温度変化に関しては，Unifast は他のものに比して 最もその依存性が少く, Duralay, Palavit の順に強 く影響されているのがみられた。

今後は，パターン用レジンの前述した他の諸性質を明 らかにするために更に夹験を重ねていきたいと考えてい る.

\section{5.小腸の新しい Aromatic amrinotransferase} 一ビタミン $\mathbf{B}_{6}$ 欠乏ラットでの出現一

\section{○高田 義一・野口 知雄}

(九菌大・生化)

ラットの小腸において，芳香族ア之ノ酸と2-オキソグ ルタール酸のアミノ基転移反応は之トコンドリアのアス バラギン酸：2-オキソグルタール酸アミノ基転移酵素 (GOT) によって触媒される(1)のでGOT 活性と芳香 族アミ，基転移酵素活性はいずれも同一の举郵をとるも のと思われる.ところが，ラットをビタミン $\mathrm{B}_{6}$ 灭乏食 で60日間飼育したところ, 小腸の GOT 活性が吱照の約 半分に低下したのに対し，フェニルアラニン：2-オキソ グルタル酸アミ，基転移酵素活性は約 4 倍に上昇してい た・この結果は, GOT 活性をもたない新しい芳香族ア ミノ基転移酵素がビタミン $\mathrm{B}_{6}$ 火灭ラット小腸に存在す ることを示陖している。てれを明らかにするために，正 常及びビタミン $\mathrm{B}_{6}$ 众乏ラットの小腸の抽出液をそれぞ れ等電点分画した。その結果, ビタそン $\mathrm{B}_{6}$ 炎乏ラットで は, cytosol 型 (pI 6.2) 及びミトコンドリア型 GOT （pI 9.4）の活性ピークの他に，GOT 活性を持たない フェニルアラニン: 2-オキソグルタル酸アミノ基転移酵 素（pI 8.5）の活性ピークが娭出された。この新しい芳 香族アミ，基転移酵素はビタミン $\mathrm{B}_{6}$ 火乏ラットの小腸 粘膜の cytosol に司在しており，正常及びビタミン $\mathrm{B}_{6}$ 欠乏ラットの肝, 腎, 脳, 心の抽出液には唡出されなか った．本酵素をビタミン $\mathrm{B}_{6}$ 灭乏ラットの小腸から高度 に精製し性質を明らかにした。本酵素は芳香族アミノ酸 〈フニルアラニン，トリブトファン，チロシン，5-オ キシトリプトファン) に特異性を宗し，他の L-アミノ 酸には活性を示さなかった。また，アミ，基受容体とし て2-オキソグルタール酸に特異的で他の2-オキソ酸(グ リオキシル酸, ピルビン酸, 2-オキソアジピン酸)には

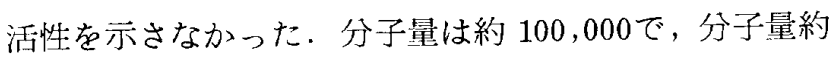


52,000 の 2 個の同一の subunit からなると推定され た、本醅素はいままでに知られているどの酥素とも異っ ており，本酻素の出䍐機構については検討中である。

1) Noguchi, T., Minatogawa, Y., Okuno, E., Nakatani, M., Morimoto, M.\& Kido,R. (1975) Biochem. J. 151, 399-406

\section{6. 数種の哺乳動物の畨列弓長と口蓋値について}

$$
\begin{aligned}
& \text { ○杉野信孝 - 山田博 - 井本 広魔 } \\
& \text { 池田 研二 (九料大・回解 } 1 \text { ) }
\end{aligned}
$$

本学口腔解学教室所蔵のブタ, イノシシ,アナグマ, タヌキの 4 種類の哺乳類動物頭蓋骨合計72個を用いて, 歯列弓抢よび口蓋形態の調查を行い，それら哺乳動物の 差異について検討老行った。

計測は, 尖端の尖鋭な Kanon の vernier calipers $(20 \mathrm{~cm}$ 用， $1 / 20 \mathrm{~mm}$ 副尺付き) と2アンペアのヒュ ズを用いて計測を行い，また計測は 3 回行い，その丑均 值をもって計測值とした，計測值の取り扱いは，まず各 々の平均値, また標準偏差 S D, を算出し, $\mathrm{t}$-分布表に より平均值の差の検定を行った。 また同一個体に扔いて 二つの項目間における相関係数 $\mathrm{r}$ 算出し，その有意差 の検定を行った．差の検定についてはすべて危険率 $5 \%$ 以下で有意差ありとした。

それらの結果を総括的にみれば以下゙のごとくである。 ブタとイノシシに扔いては上颗幽弓長 $\left(\mathrm{M}_{3}-\mathrm{M}_{3}\right)$ と上 額 $\mathrm{M}_{3}$ 部幅径の間の相関では, ブタよりもイノシシが高 い相関を示し，下䫑雨列弓長 $\left(\mathrm{M}_{2}-\mathrm{M}_{2}\right)$ と下顎 $\mathrm{M}_{2}$ 部 幅径間の相関では，ブタが高い逆相関を示しているのに 対してイノシシは正の相関を示している．また下顎歯列 弓長 $\left(M_{3}-M_{3}\right)$ と下顎 $M_{3}$ 部幅径間の相関ではイノシ シが高い相関を示すのに対して，ブタではほとんど相関 は涩めら狆ず，全く刘称的な結果を示している，狸に抏

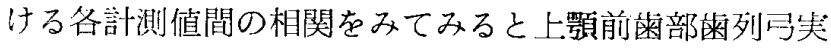

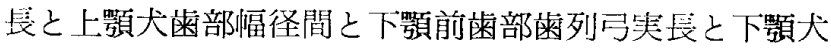
歯部幅径間と比較すると相関係数は上顎の值が大きくブ タの場合と同様でイノシシおよび穴熊とは逆である。ま た示数值より判断すれば雬列弓の幅に対して長さが相刘 的に最も長いのはイ,シシで以下ブタ，タヌキ，アナグ マの順となっている。

今後, 他の哺乳動物についても同様の研究を行い, 比 較検討在行っていきたいと思っている。

\section{7. 前処膡として稪正治療を必要とした補綴治験例}

\section{○村上 繁樹・平川 郁夫・脇 博泰 \\ (九歯大・補綴 2) \\ 佐藤 英彦 (九雨大・矯正)}

前処置として镉正治療を行わなければ，満足できる補 緅物か泎製できない2 症例に遭遇したので報告する。

症例 1 は 9 墄女性で，反刘咬合を主訴として来院し た. 本学矯正科で下顝の遠心移動, 咬合挙上, 43134 の唇倒移動および 3 の 6 年間で治療を終了した。

成長終了後の 18 歳で補緅治療を行った。顎中, 側

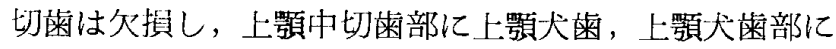
上顎第 1 小曰霜が植立していた。そてで，犬歯を中切歯 に，第 1 小四霜を大雨に補綴的に形態修正し，金属焼付 陶材冠によるブリッジを装着した。

症例 2 は13歳女性で反刘咬合, 空腺歯列弓を主訴とし

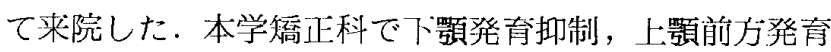
促進，上頢前歯の唇側傾斜，正中離開，ずれの改善, 1 の主下, $\sqrt{6}$ の upright および個々の蒾の排列を行い, 約 3 年で治療を終了した。

成長終了後の 19 歳で補緅治療を行なった。 $\frac{542}{4} \frac{234}{45}$ は 久損していた， 臼菌部の宷冠長は短く，保持形態付与の

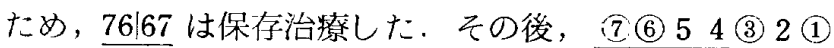
之 (1) 234 (5)(6) (7), (7)(6) 4 之i(3) 45 (6) の金虐焼付 陶材冠（咬合面は澓材）のブリッジを装着した。

なお，2 例とも若年者であるので，とくにブリッジの 予後観察が重要であると思われる.

\section{8. 下顎骨オトガイ部に発生した囊胞性エナメル上皮腫 の 1 例}

\section{○四倉 圭一・鬼塚 啓史・杉原 利英 魚山 嘉光・山田 長敬 (九歯大・ 口外 1 )}

エナメル上皮腫は他の一般腫煌に比較するとその発生 頻度は低いが，口腔外科領域においては比較的しばしば 遭遇する疾患である。また本症病理組織学的にもその 特買な腫煬構造の多様性から興味ある腫煌として從来よ り多くの報告がなされている。

今回，我々は18歳男性:の下顎オトガイ部に発生した。

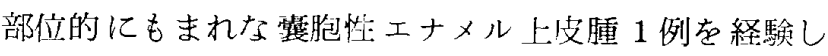
た。

臨床的に颚骨囊胞と囊胞性エナメル上皮腫の鑑別は困 